\title{
Ectopic pregnancy: a five year retrospective study in a tertiary care hospital
}

\author{
Arti Gupta Tuli*, Sunita Goyal, David Livingston, Amritha Susan Kurian
}

Department of Obstetrics and Gynaecology, Christian Medical College and Hospital, Ludhiana, Punjab, India

Received: 29 July 2015

Revised: 16 August 2015

Accepted: 17 August 2015

\section{*Correspondence:}

Dr. Arti Gupta Tuli,

E-mail: tuliarti@yahoo.co.in

Copyright: $\odot$ the author(s), publisher and licensee Medip Academy. This is an open-access article distributed under the terms of the Creative Commons Attribution Non-Commercial License, which permits unrestricted non-commercial use, distribution, and reproduction in any medium, provided the original work is properly cited.

\begin{abstract}
Background: A ruptured ectopic pregnancy is a true emergency and remains the leading cause of pregnancy related first trimester deaths. The objective was to study the clinical profile of ectopic pregnancy in a tertiary care hospital. Methods: It was a retrospective study conducted at Christian Medical College \& Hospital, Ludhiana from 1st June 2009 to 31st May 2014. A total of 108 patients with ectopic pregnancy were analysed on clinical presentation, clinical findings, investigations, operative findings and outcome.

Results: A majority of women (44.44\%) were in the age group of $26-30$ years and 50\% were multigravida. Risk factors were identifiable in $71.29 \%$ patients. Amenorrhea $(91.6 \%)$ and pain abdomen $(92.82 \%)$ were the most common presenting symptoms. Twenty $(18.51 \%)$ women had laparoscopy, $72(66.67 \%)$ underwent an exploratory laparotomy and sixteen (14.81\%) women received medical management. There were no maternal deaths and postoperative morbidity in the form of febrile illness $(11.11 \%)$, and wound sepsis $(4.62 \%)$ was seen.

Conclusions: Ectopic pregnancy still remains one of the major causes of maternal morbidity and mortality. Early diagnosis and referral in hemodynamically stable state along with use of minimal access surgery or medical management can change the scenario of ectopic pregnancy in the developing world.
\end{abstract}

Keywords: Ectopic, Pregnancy, Amenorrhoea

\section{INTRODUCTION}

Ectopic pregnancy is any pregnancy that occurs outside the uterine cavity. A ruptured ectopic pregnancy is a true emergency and remains the leading cause of pregnancy related first trimester deaths. ${ }^{1}$ The number of ectopic pregnancies has increased dramatically in the past few decades. The rise can be attributed partly to increase in certain risk factors but mostly to improved diagnostics. ${ }^{2}$ Any woman of reproductive age presenting with abdominal pain, vaginal bleeding, syncope or hypotension with or without amenorrhoea with pregnancy test positive should be provisionally diagnosed as an ectopic pregnancy unless proved otherwise. The evaluation may include a combination of determination of urine and serum human chorionic gonadotrophin (hCG) levels and ultrasonography. Key to the diagnosis is determination of the presence or absence of an intrauterine gestational sac correlated with serum $\beta$ hCG levels. Greater awareness of risk factors and improved technology (biochemical markers and ultrasonography) allows ectopic pregnancy to be identified before the development of life threatening events.

The importance of ectopic pregnancy is peculiar in our country because rather than join the global trend of early diagnosis and conservative approach in management, we are challenged by late presentation and rupture in most cases. 


\section{Aims and objectives}

This study was undertaken to study the incidence, clinical presentations, risk factors, management of cases and outcome of all cases of ectopic pregnancy that presented to our centre over a period of five years.

\section{METHODS}

This is a retrospective study conducted at Christian Medical College \& Hospital, Ludhiana from 1st June 2009 to 31st May 2014. All women who presented to our hospital with ectopic pregnancy were analysed from the available hospital documents (bedside records, history, operation theatre records and yearly audit report).The data collected was in respect to the following:

$\begin{array}{ll}\text { 1. } & \text { Age } \\ \text { 2. } & \text { Parity } \\ \text { 3. } & \text { Chief complaints } \\ \text { 4. } & \text { Period of amennorhea } \\ \text { 5. } & \text { Any risk factors for ectopic pregnancy } \\ \text { 6. } & \text { Evidence of hypovolemia } \\ \text { 7. } & \text { hCG in urine/serum } \\ \text { 8. } & \text { Mode of treatment } \\ \text { 9. } & \text { Operative findings } \\ \text { 10. } & \text { Outcome of patients }\end{array}$

\section{RESULTS}

The total number of deliveries in our institution in the study period was 6477 and the total number of ectopic pregnancies during this time was 108 . The incidence of ectopic pregnancy in our study is $1.66 \%$.

A majority of women who presented with ectopic pregnancy were in the age group of 26-30 years (44.44\%) and $50 \%$ had one previous pregnancy. On evaluation of the risk factors, it was found that 77 women $(71.29 \%)$ had one or the other risk factor which included history of pelvic inflammatory disease (PID) in 28 (36.36\%), previous abortion in $22(28.57 \%)$, history of infertility treatment in $10(12.98 \%)$, previous ectopic pregnancy in $7(9.09 \%)$, tubal ligation in $7(9.09 \%)$, IUCD use in 3 women $(3.89 \%)$ (Table 1). 31 patients had no identifiable risk factor.

Table 1: Distribution according to risk factors.

\begin{tabular}{|lll|} 
Risk factor & $\begin{array}{l}\text { Number } \\
(\mathrm{n}=77)\end{array}$ & $\begin{array}{l}\text { Percentage } \\
(\%)\end{array}$ \\
\hline PID & 28 & 36.36 \\
\hline $\begin{array}{l}\text { Previous } \\
\text { abortion }\end{array}$ & 22 & 28.57 \\
\hline $\begin{array}{l}\text { Infertility } \\
\text { treatment }\end{array}$ & 10 & 12.98 \\
\hline Tubal ligation & 7 & 9.09 \\
\hline Previous ectopic & 7 & 9.09 \\
\hline IUCD use & 3 & 3.89 \\
\hline
\end{tabular}

Amenorrhea (91.6\%), pain abdomen (92.82\%) along with vaginal bleeding $(73.80 \%)$ were the usual presenting complaints. Presence of tachycardia (70.24\%) and abdominal tenderness $(81.77 \%)$ were the most consistent clinical findings. Bedside urine pregnancy test (hCG) was positive in $93.51 \%$ women.

Laparoscopic management and peritoneal lavage was done in $20(18.51 \%)$ women with ectopic pregnancy. Laparotomy was done in $72(66.67 \%)$ women. Only 16 patients $(14.81 \%)$ were fit and willing for medical management of which one woman had a failure and an urgent laparoscopy was performed on her (Table 2). One patient had failure of medical treatment and was taken up for laparoscopy.

Table 2: Distribution according to mode of treatment.

\begin{tabular}{|lll|}
\hline $\begin{array}{l}\text { Mode of } \\
\text { treatment }\end{array}$ & $\begin{array}{l}\text { Number } \\
(\mathrm{n}=108)\end{array}$ & $\begin{array}{l}\text { Percentage } \\
(\%)\end{array}$ \\
\hline Laparotomy & 72 & 66.67 \\
\hline Laparoscopy & 20 & 18.51 \\
\hline $\begin{array}{l}\text { Medical } \\
\text { management }\end{array}$ & 16 & 14.81 \\
\hline
\end{tabular}

Table 3 shows the operative findings on laparotomy. There was tubal rupture in $73(78.49 \%)$, Chronic ectopic in $10(10.75 \%)$, tubal abortions in $5(5.37 \%)$ and unruptured tubal pregnancy in $5(5.37 \%)$ women with ectopic pregnancy.

Table 3: Distribution according to operative findings on laparotomy and laparoscopy.

\begin{tabular}{|lll|}
$\begin{array}{l}\text { Operative } \\
\text { findings }\end{array}$ & $\begin{array}{l}\text { Number } \\
(\mathbf{n = 9 3})\end{array}$ & $\begin{array}{l}\text { Percentage } \\
(\%)\end{array}$ \\
\hline Tubal rupture & 73 & 78.49 \\
\hline $\begin{array}{l}\text { Chronic } \\
\text { ectopic }\end{array}$ & 10 & 10.75 \\
\hline Tubal abortion & 5 & 5.37 \\
\hline Unruptured & 5 & 5.37 \\
\hline
\end{tabular}

Table 4: Site of tubal rupture in ectopic pregnancy.

\begin{tabular}{|lll|}
$\begin{array}{l}\text { Site of ectopic } \\
\text { pregnancy }\end{array}$ & $\begin{array}{l}\text { Number } \\
(\mathrm{n}=73)\end{array}$ & $\begin{array}{l}\text { Percentage } \\
(\%)\end{array}$ \\
\hline Ampulla & 48 & 65.75 \\
\hline Isthmus & 10 & 13.69 \\
\hline Infundibular & 7 & 9.58 \\
\hline Cornual & 6 & 8.21 \\
\hline Ovarian & 2 & 2.73 \\
\hline
\end{tabular}

Majority of the cases had rupture in the ampullary area $(65.75 \%)$ followed by rupture in isthmic area. There were 6 cases of cornual rupture and 2 cases of ovarian pregnancy (Table 4). Most of the patients presented with anaemia of different degrees. Severe anaemia was seen in 18 patients and 6 patients had very severe anaemia. Blood 
transfusion was required in 66 patients either intraoperative or postoperative. No transfusion was required in 42 patients. (Table 5) There were no maternal deaths due to ectopic pregnancy in the study period. Postoperative morbidity in the form of febrile illness and wound infection was seen in $12(11.11 \%)$ and $5(4.62 \%)$ women respectively.

Table 5: Haemoglobin level and blood transfusion.

\begin{tabular}{|lcc|}
\hline $\begin{array}{l}\text { Pre-Operative } \\
\text { Hb }(\mathrm{gmo/dl})\end{array}$ & $\begin{array}{l}\text { Number } \\
(\mathrm{n}=\mathbf{1 0 8})\end{array}$ & $\begin{array}{l}\text { Percentage } \\
(\%)\end{array}$ \\
\hline$<4$ & 6 & 5.5 \\
\hline $4-6$ & 18 & 16.66 \\
\hline $7-10$ & 46 & 42.59 \\
\hline$>10$ & 38 & 35.18 \\
\hline Number of units of blood transfusion \\
\hline Nil & 42 & 38.88 \\
\hline $1-2 \mathrm{U}$ & 34 & 31.48 \\
\hline$>2 \mathrm{U}$ & 32 & 29.62 \\
\hline
\end{tabular}

\section{DISCUSSION}

Ectopic pregnancy is a high risk condition, a nightmare for all gynaecologists and reproductive challenge for a patient. It is a heterogeneous disease which presents itself in a bewildering variety of anatomical, physiological and clinical expressions. There is considerable regional variation in its incidence and globally, it has been on the rise over the past three decades. Worldwide, ectopic pregnancy complicates $0.25-2.0 \%$ of all pregnancies. ${ }^{3}$ The incidence of ectopic pregnancy in our study is $1.66 \%$. It correlates well with other studies.4,5 The increase in incidence is associated with rise in the incidence of sexually transmitted infections (STIs) and salpingitis, advances in assisted reproductive technology, tubal surgeries, female contraception and earlier diagnosis with more sensitive methods. ${ }^{2}$

More cases were seen between age group 26-30 years. There are different studies with similar results.,6,7 Our study showed that $50 \%$ had one previous pregnancy. Some studies are showing increased risk of ectopic pregnancy in nulliparous or primiparous which is conflicting with our results. ${ }^{2,8}$ Others have reported similar figures. ${ }^{6}$

No risk factor was found in 31 patients. 77 patients presented with one or the other risk factor. The commonest risk factor was PID (36.36\%). Salpingitis and PID increases the risk of ectopic pregnancy by 6-10 fold. ${ }^{9}$ Many studies support our result. ${ }^{2,3,9}$ Both the increased incidence of STIs resulting in salpingitis and the efficacy of antibiotic therapy in preventing total tubal occlusion after an episode of salpingitis are related to the increasing incidence of ectopic pregnancy. ${ }^{10}$ Chlamydia trachomatis (most common) and Mycoplasma hominis infection significantly increase the risk of ectopic pregnancy with each episode causing $10 \%$ chance of ectopic pregnancy. So PID constitutes an important risk factor.

In our study previous abortions constituted an important risk factor $(28.57 \%)$ irrespective of the fact whether it is induced or spontaneous. Prior induced abortion significantly increases the risk of ectopic pregnancy. ${ }^{6,9} \mathrm{~A}$ study found that the risk of ectopic pregnancy was higher in women who underwent medical abortion as compared to women who underwent surgical abortion. They interpreted this association as a consequence of infection. ${ }^{11}$ Previous spontaneous abortions increased the risk of ectopic pregnancy, especially for women with three or more spontaneous abortions. ${ }^{11}$ So any type of abortion is a risk factor for ectopic pregnancy.

The incidence of ectopic pregnancy following infertility treatment is much higher as compared to spontaneous pregnancies. Ectopic pregnancy following infertility treatment occurred in $12.98 \%$ patients in our study. However, as ectopic pregnancy is known risk factor for subsequent infertility, the links between ectopic pregnancy and infertility which seem to be mutual risk factors are likely to be complex. , $^{2,11}$

Shaista et $\mathrm{al}^{12}$ found an increased incidence of ectopic pregnancies $(9 \%)$ in women with previous history of ectopic pregnancy which is corroborated by our study $(9.09 \%)$. After one ectopic pregnancy, there is a $10 \%$ risk of having a second ectopic pregnancy. After two ectopics risk increases to $25 \% .9$ In some other studies the incidence is less. ${ }^{2,13}$

There is $15-50 \%$ chance of being ectopic if pregnancy occurs following tubal surgeries. ${ }^{9}$ Prior tubal ligation accounted for $9.09 \%$ of ectopic in present study similar to others.2 Intrauterine contraceptive device prevents intrauterine pregnancy effectively but tubal implantation to a lesser extent. ${ }^{9}$ There were 3 cases $(3.89 \%)$ of ectopic pregnancy with IUCD use in our study correlating with other studies. ${ }^{11}$

Most of the cases $(78.49 \%)$ presented with ruptured ectopic pregnancy making the scenario clear that still in India most of the patients present late, may be due to failure of making early diagnosis at various level of healthcare delivery system. As a result in our study majority of the women $(66.67 \%)$ had a laparotomy because of unstable condition and hemoperitoneum. Laparotomy with salpingectomy was the most common modality of treatment in most of the other studies. ${ }^{2,3,14}$ In some studies lack of expertise in laproscopy and presentation of the patient late in night when seniors are not around also led to increase in rate of laparotomy. $3,15,16$ For women who present early with ectopic pregnancy laproscopy and medical management with methotrexate remains an attractive option as was seen in our study and by Olofsson et al. ${ }^{2,17}$ We gave medical management in 16 patients. Methotrexate was given as a single dose of $50 \mathrm{mg} / \mathrm{m}^{2} \mathrm{i} / \mathrm{m}$. Only one case had a failure and so she underwent laparotomy. Laproscopy was done in 20 cases 
who were hemodynamically stable but didn't fullfill criteria for medical management.

The tubes remained the commonest site of ectopic pregnancy and ampulla being commonly affected $(65.75 \%)$ in our study correlating with other studies. ${ }^{2,13}$ Ovarian pregnancies are very rare only about $0.5 \%$ of ectopics occur in the ovary. ${ }^{9,10}$ There were 2 cases of ruptured ovarian pregnancy in our study $(2.73 \%)$. Preoperative haemoglobin levels ranged from $2 \mathrm{gm} \%$ $11 \mathrm{gm} \%$. 22.22\% had severe anemia with $\mathrm{Hb} \%$ level below $6 \mathrm{gm} \%$. Most of the patients $(61.11 \%)$ had blood transfusions intraoperatively and postoperatively.

\section{CONCLUSIONS}

Ectopic pregnancy still remains one of the major causes of maternal morbidity and mortality. Early diagnosis and referral in hemodynamically stable state along with the use of minimal access surgery or medical management can change the scenario of ectopic pregnancy in the developing world and at same time preserve the potential for future fertility.

Funding: No funding sources

Conflict of interest: None declared

Ethical approval: The study was approved by the Institutional Ethics Committee

\section{REFERENCES}

1. Okunlola MA, Adesina OA, Adekunle AO. Repeat ipsilateral ectopic gestation- a series of three cases. African J Medicine and Med Science 2006;35:173-5.

2. Pendyala Sujata, Basanta Kumar Pati, Gangadhar Sahoo et al. Ectopic Pregnancy - A Five Year Review. Indian Journal of Perinatology and Reproductive Biology. 2014;04(02):21-4.

3. Yakasai IA, Abdullahi J, Abubakar IS. Management of ectopic pregnancy in Aminu Kano teaching hospital Kano Nigeria: A 3 year. Global Advanced Research Journal of Medicine and Medical Sciences. August 2012;1(7):181-5.

4. Farquar CM. Ectopic pregnancy. Lancet 2005;366: 583-91.

5. Chanda Karki, Anjana Karki, Kundu Yangzom. Ectopic pregnancy and its effect on future fertility. South Asian Federation of Obstetrics and Gynecology. 2009;1(1):35-9.
6. AO Igwegbe, Gu Eleje, BC Okpola. An appraisal of the management of ectopic pregnancy in a Nigerian Tertiary Hospital, Ann Med Health Science Res. 2013;3(2):166-70.

7. Maifa Abdulaziz Al Turki, ISRN Obstetrics and Gynaecology Volume 2013(2013), http//dx.doi.org/10.1155/2013/97251.

8. Majhi AK, Roy N, Karmakar KS, Banerjee PK. Ectopic pregnancy - An analysis of 180 cases. J Indian Med Assoc. 2007;105:308-12.

9. Dutta DC, Haemorrhage in Early pregnancy. In: Koner H, editor. Textbook of Obstetrics. Revised reprint of 7th edition: Nov. 2013; 177-190.

10. Te Linde's, Ectopic Pregnancy. In: John A. Rock, Howard W. Jones III editor. Operative Gynecology. 10th edition, 7th Indian Reprint, 2014; 798-824.

11. Bouyer J, Coste J, Shojae T, Poyl JL, Fernandez H, Gerband L et al. Risk factors for ectopic pregnancy: A comprehensive analysis based on a large case control population based studies in France. Am J Epidemiol. 2003;157:185-94.

12. Shaista A, Bothaina AW, Hussain AS. Frequency of ectopic pregnancy in a medical centre, Kingdom of Saudi Arabia. JPMA 2011, 61:221.

13. Rashmi A Gaddagi, AP Chandrashekhar. A clinical study of ectopic pregnancy. Journal of clinical and diagnostic Research. 2012;6(5):867-9.

14. Chakraborty S, Mukherjee S, Roy J. Ectopic pregnancy- a study in a tertiary care centre. Ind $\mathbf{J}$ Perinat \& Reprod Biol 2011;1(3):35-7.

15. Patrick T, Yolande H, Nathalie $G$ et al. Ectopic Pregnancy in Conakry, Guinea. Bull World Health Organ 2002;80(5):365-70.

16. Rose IA, Ayodeji O, Sylvia A et al. Risk factors for Ectopic Pregnancy in Lagos, Nigeria. Acta Obstet. Gynecol. Scand. 2005;84:184-8.

17. Olofsson JI, Poromaa IS, Ottander U, Kjellberg L, Damber MG. Clinical and pregnancy outcome following ectopic pregnancy; a prospective study comparing expectancy, surgery and systemic methotrexate treatment. Acta Obstet Gynaecol Scand 2001;80(8):744-9.

Cite this article as: Tuli AG, Goyal S, Livingston D,

Kurian AS. Ectopic pregnancy: a five year retrospective study in a tertiary care hospital. Int $\mathbf{J}$ Reprod Contracept Obstet Gynecol 2015;4:1400-3. 